\title{
Chemical characterization and antioxidant capacity of 'Cambui' (Myrciaria tenella) products
}

\author{
Ana Cecília Poloni Rybka', Aline Camarão Telles Biasoto Marques', \\ Ana Júlia Araújo², Rita de Cassia Mirela Resende Nassur ${ }^{3 *}$ \\ 'Brazilian Agricultural Research Corporation, Petrolina, Brazil \\ ${ }^{2}$ Federal Institute of Education, Science and Technology of the Sertão, Petrolina, Brazil \\ 3University of the State of Bahia, Salvador, Brazil. \\ ${ }^{*}$ Corresponding author, e-mail: ritarnassur@hotmail.com
}

\begin{abstract}
Very little information is found about the 'Cambui' products and the fruit is almost unexplored by the Brazilian agriculture or extractive activities. The present study aimed to characterize the physicochemical composition and antioxidant capacity of the juice, jam and fermented beverage obtained from 'Cambui' fruits aiming to add value to the fruit and generate alternatives to Brazilian extractive population. These products were elaborated in small scale of production. The 'Cambuí' juice was prepared using the method of steam distillation and the jam was obtained from the residue of the juice with addition of sugar and citric acid. The 'Cambuí' fermented beverage was elaborated using procedures of winemaking. For the evaluation of the products quality, chemical analysis and evaluation of the antioxidant capacity were performed. All products presented high concentrations of the studied variables, when comparing to grape wines, fruit jams and grape juices. The 'Cambui' products can be considered sources of antocyanins and other phenolic compounds, with high antioxidant potential. The use of 'Cambui' has potential for the development of juice, jam and fermented beverage, and these products can be an alternative to add value to fruit and generate income for populations that work with which income depend on extractive activities.
\end{abstract}

Keywords: fruit juice, fruit wine, jam

\section{Introduction}

The 'Cambui' tree (Myrciaria tenella) belongs to the Myrtaceae family, originating from South America (Sessa et al., 2016), South (Belem et al. 2016; Tonetti \& Biondi, 2016; Cordero et al. 2016) and Southeast states of Brazil, it can also be found in the Northeast of the country (Silva et al., 2012), as in areas of the 'Chapada Diamantina', Bahia State. It is mainly used as an ornamental plant and its wood is used for fence posts, tools and firewood (Lorenzi 2000). Its fruit is named 'Cambui' in Brazil, with a rounded shape, with one to three seeds and color ranging from yellow, deep red and dark violet, depending on the maturity stage. Its fruits are glabrous and bright globose berries, red or dark purplish when ripe (Lédo et al. 2014).

According to the few studies that evaluated the chemical composition 'Cambui' it is possible to conclude that this fruit has a diameter between 0.5-1.0 cm, an average flesh weight of 0.60 to $0.15 \mathrm{~g}$, pH of 3.3-4.8, total soluble solids around $10.5^{\circ}$ Brix, ascorbic acid content of $110 \mathrm{mg} \cdot 100 \mathrm{~g}^{-1}$, with significant amounts of lipids $(>33 \%)$ and proteins (>7.5\%) based on dried fruit (Pinheiro et al. 2011).

This fruit is able to produce essential oil rich in volatile compounds and Apel et al. (2010) identified 34 volatiles in the 'Cambuí' essential oil, with higher contents of $\beta$-caryophyllene 
terpenes (25\%) and spathulenol (10\%). The antiinflammatory effect of 'Cambuí' essential oil was investigated by the authors 'in vitro' and 'in vivo' and the use of the essential oil significantly reduced the chemotaxis of neutrophils treated, with $93 \%$ of inhibition rate.

The evaluation regarding the chemical composition of fresh 'Cambui' reveal that it is an attractive option for human consumption, being necessary further studies about the species. This result probably shows potential for use in the agroindustry, both for the development of products by industrial or handmade scales, being and interesting alternative for familiar agriculture or small extractive growers and farmers. Currently, very little information is found about the 'Cambui' processing and this fruit is almost unexplored by the Brazilian agriculture or extractivism. In this sense, this study aimed to carry out the chemical characterization and evaluation of the antioxidant capacity of 'Cambui's' juice, jam and fermented alcoholic beverage.

\section{Material and methods}

Ninety kilograms (approximately 198 pounds) of 'Cambui' were harvest in the municipality of Morro do Chapéu - BA, Brazil, when the soluble solids content reached $11^{\circ}$ Brix. The fruits were immediately transported to the Embrapa Semi-Arid, Petrolina - PE, Brazil, to proceed the development of the products. Two products were elaborated- the juice and the fermented beverage and a subproduct- the jam, which was obtained from the juice residue. For the products preparation, the methodology suggested and described by Marques et al. (2013) were followed. All elaborations were conducted in triplicate.

For the preparation of the fermented alcoholic beverage (wine), glass bottles with $20 \mathrm{~L}$ of capacity adapted with Müller valve to control the entry of oxygen and allow the carbon dioxide output were used, by adding $0.01 \mathrm{~g} \mathrm{~L}^{-1}$ of the preservative potassium metabissulfite and 30 $\mathrm{mg} . \mathrm{L}^{-1}$ of Saccharomyces cerevisiae commercial yeast, which was previously activated at $35^{\circ} \mathrm{C}$ for 40 minutes, and sucrose (36 $\left.\mathrm{g.L}^{-1}\right)$ in the form of crystallized sugar to increase the alcohol content of the beverage.
Must preparation: for the obtainment of $10 \mathrm{~L}$ of fermented beverage, $20 \mathrm{Kg}$ of healthy and mature cambui fruits were used, stored in a cold room at $8 \pm 2{ }^{\circ} \mathrm{C}$ since harvest. Fruit were weighted, mashed and placed in a $20 \mathrm{~L}$ container, adding $0,1 \mathrm{~g} / \mathrm{L}$ of potassium metabissulfite, avoiding enzymatic reactions and not desirable fermentation. For the alcoholic fermentation, the Saccharomyces cerevisiae yeast was added $10.35 \mathrm{~g} / \mathrm{L}$ of the yeast in $10 \mathrm{~mL}$ of water previously heated at $35^{\circ} \mathrm{C}$ ). Fermentation was carried out at a temperature of $22 \pm 2^{\circ} \mathrm{C}$ during 20 days. At the same time with the alcoholic fermentation, the maceration was carried out, remaining fruits for 10 days in contact with the fermenting must to promote a better extraction of film compounds, seed and pulp. After fermentation, stabilization was performed in a cold $\left(0^{\circ} \mathrm{C}\right)$ room for 30 days to improve the clarity and stability of the beverage. After this period, the fermented beverage was bottled and stored horizontally in a room with control of temperature $\left(18^{\circ} \mathrm{C}\right)$, until analysis.

For the juice preparation, $10 \mathrm{~kg}$ (approximately 22 pounds) of fruits were used for each replicate, being previously sanitized with 200 ppm of active chlorine solution by immersion during 20 minutes. For extraction of the 'Cambui' juice, the stem extraction was used with the aid of a stainless steel juicer, being a simple technique with low cost and that can provide the preparation of pasteurized juice with very similar characteristics when compared to the fresh fruit. The extraction of juice was performed for 60 minutes at $75 \pm 5^{\circ} \mathrm{C}$, then previously sterilized glass bottles $\left(75^{\circ} \mathrm{C}\right)$ was filled by the hot juice. The product was cooled at a room with controlled temperature and stored in a horizontal position at the same condition $\left(18^{\circ} \mathrm{C}\right)$, until analysis.

To obtain the jam, the residue of the juice preparation was used, with addition of $0.6 \mathrm{~kg}$ of sugar and $1.3 \mathrm{~g}$ of citric acid per $\mathrm{kg}$ (2.2 pounds) of the 'Cambuí' residue. The mixture was heated at $90^{\circ} \mathrm{C}$ for 60 minutes and mixed constantly to prevent fouling. Then the product was passed through a sieve. The obtained jam was then bottled hot $\left(85^{\circ} \mathrm{C}\right)$ in previously sterilized glass vials and cooled in a room with temperature control.

The physico-chemical analysis were performed one month after the preparation 
of the products. For the evaluation of the titratable acidity ( $\left.\mathrm{g} \cdot \mathrm{L}^{-1}\right)$ and the relative density, the procedures described by the Associaton of Official Analytical Chemists (AOAC 2016) were used. The hydrogenionic potential $(\mathrm{pH})$ was directly determined in the sample with the aid of a $\mathrm{pH}$ meter (Tecnal, Tec-3MP model), previously calibrated. The alcohol content (\%v/v) was determined by hydrostatic balance (Model Super Gilbertini Alcomat), after distillation of the sample by an automatic Oenochemical Electronic Distilling (Gilbertini model Super E. D. E.). In the same hydrostatic scale, the dry matter content, density and soluble solids ('Brix) were evaluated. The total monomeric anthocyanins were determined by the method described by Rizzon (2010), using a spectrophotometer Biomol, model SP-220. In the same spectrophotometer, it was determined the total polyphenol index (TPI) for the fermented beverage and the juice, performing the direct reading of the samples at $280 \mathrm{~nm}$ of absorbance (Harbertson \& Spayd 2006), and the color intensity, adding up readings obtained at wavelengths of 420,520 and $620 \mathrm{~nm}$ (Ough \& Amerine 1988). The antioxidant activity was evaluated using the reagent 2,2-diphenyl1-picrylhydrazyl (DPPH), based on the method of Brand-Williams et al. (1995) and adapted by Rybka (2010).

The test results were submitted to ANOVA and Tukey test ( $\mathrm{p} \leq 0.05$ ) using the statistical software Statistical Analysis System - SAS ${ }^{\circledR}$, version 9.3.1.

\section{Results and Discussion}

The obtained results for the chemical analysis and for the evaluation of the antioxidant capacity of the fermented beverage, juice and jam are presented on Tables 1 and 2, respectively. The fermented beverage of 'Cambui'

Table 1. Results for the physic-chemical analysis performed on 'Cambui' products.

\begin{tabular}{|c|c|c|c|c|c|c|c|c|}
\hline Product ${ }^{1}$ & $\mathrm{pH}$ & $\begin{array}{l}\text { Density } \\
\mathrm{g} / \mathrm{cm}^{3}\end{array}$ & $\begin{array}{l}\text { Total } \\
\text { acidity }\end{array}$ & $\begin{array}{c}\text { Total } \\
\text { polyphenol } \\
\text { index (IPT) }\end{array}$ & $\begin{array}{c}\text { Total } \\
\text { antocyanins }^{3}\end{array}$ & $\begin{array}{l}\text { Volatile } \\
\text { acidity }^{4}\end{array}$ & $\begin{array}{l}\text { Soluble } \\
\text { solids }\end{array}$ & Color index 6 \\
\hline Beverage & $3.3^{b}$ & 1.032 & $31.6^{a}$ & $166.3^{\mathrm{b}}$ & $250.9^{b}$ & $1.1^{a}$ & - & $61.5^{c}$ \\
\hline Juice & $3.4^{\mathrm{a}}$ & - & $17.6^{b}$ & $175.3^{a}$ & $311.7^{a}$ & $0.5^{b}$ & $10.9^{b}$ & $79.6^{a}$ \\
\hline Jam & $3.2^{c}$ & - & $12.4^{c}$ & $175.0^{a}$ & $120.3^{c}$ & - & $79 a$ & $63.1^{\mathrm{b}}$ \\
\hline
\end{tabular}

Table 2. Results for the antioxidant capacity using the DPPH methodology for the 'Cambui' products.

\begin{tabular}{|c|c|}
\hline Product' & $\begin{array}{c}\text { Antioxidant Capacity } \\
(\mu \mathrm{g} \text { EAA.100ml }\end{array}$ \\
\hline Fermented Beverage & $1.055,15^{c}$ \\
\hline Juice & $1.083,54^{\mathrm{a}}$ \\
\hline 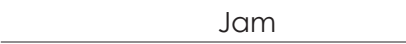 & $1.081,18^{b}$ \\
\hline
\end{tabular}

presented reasonable alcohol content (11.3\%v/v) and low $\mathrm{pH}$ (3.3), factors that contribute to a good chemical and microbiological stability of an alcoholic beverage. The drink also showed high anthocyanin (250.9 mg.100 $\left.\mathrm{mL}^{-1}\right)$ and total polyphenol (166.3) contents, and intense color (Table 1). Torres et al. (2013) found higher anthocyanin content in wines from Syrah, Cabernet Sauvignon (Vitis vinifera L.) and Petit Verdot (Vitis vinifera L.) varieties of 118, 106 and $123 \mathrm{mg} \cdot 100 \mathrm{~mL}^{-1}$, respectivelly, values lower than the observed for the 'Cambuí' fermented beverage. Analyzed by the DPPH method, the fermented beverage also showed high antioxidant potential (1055.15 $\mu \mathrm{mol}$ EAA. $100 \mathrm{ml}^{-1}$ ), as can be seen in Table 1, possibly due to the high content of anthocyanins and polyphenols of the beverage. Picinelli Lobo et al. (2009) found in ciders an average of $290 \mu \mathrm{mol}$ EAA. $100 \mathrm{~mL}^{-1}$, being possible to conclude that the antioxidant capacity of the 'Cambuí' fermented beverage is about three times higher than the cider. 
The 'Cambui' juice presented $\mathrm{pH}$ value of 3.4, similar to that observed in grape juices evaluated by Lima et al. (2014) and Rizzon \& Link (2006). The soluble solids content of the 'Cambui' juice was $10.9^{\circ}$ Brix, content that can also be compared to the value related by Rizzon \& Link (2006), evaluating grape juices, that ranged between 12.2 and $13.1^{\circ}$ Brix. The color of the Cambuí juice was much more intense than the color of all grape juices evaluated by Lima et al. (2014), whose result is the sum of the reading absorbances at wavelengths of 420,520 and 620 $\mathrm{nm}$, ranged from 2.78 to 11.15 , while the intensity of the 'Cambuí' juice color was 79.6.

The 'Cambui' juice, similar to the fermented beverage, also presented high antioxidant potential, being observed values of $1083.54 \mu \mathrm{mol}$ EAA.100 $\mathrm{mL}^{-1}$ (Table 2), standing out significantly $(p=0.05)$ when compared to the content observed for the fermented beverage and the jam, possibly due to the higher concentration of total polyphenols (175.3) and anthocyanins $\left(311.7 \mathrm{mg} .100 \mathrm{~mL}^{-1}\right)$ of this product (Table 1). Zdunic et al. (2016) observed an increase in the phenolic content comparing pumpkin juice to the 'in natura' fruit, from 93.0 $\mu \mathrm{g}$ GAE/g of pumpkin juice to $905.9 \mu \mathrm{g} \mathrm{GAE} / \mathrm{g}$ of fresh vegetable, demonstrating that the process can decrease the phenolic content in fruits and vegetables. The anthocyanins content of 'Cambui' juice was higher than that found by Lima et al. (2014) for grape juices produced with different grape varieties (BRS Cora, Magna BRS and BRS Violeta), whose maximum value observed was $46.4 \mathrm{mg} .100 \mathrm{~mL}^{-1}$.

The 'Cambui' jam, although processed from the juice residue, presented antioxidant capacity of $\left(1081.18 \mu \mathrm{mol}\right.$ EAA.100 $\left.\mathrm{mL}^{-1}\right)$, high content of total polyphenols (175.0) and high concentration of anthocyanins $\left(120,3 \mathrm{mg} \cdot 100 \mathrm{~g}^{-1}\right)$. The anthocyanins content of the 'Cambui' jam was similar to anthocyanin content quantified by Mota (2006) in jams elaborated with seven blackberry cultivars, which contents

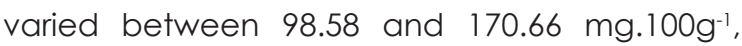
being considered a product rich in phenolic compounds by the author.

Compared to other fruits, the anthocyanins content observed in 'Cambui' juice and fermented beverage are similar to the contents of fresh 'jabuticaba' (314 mg.100 $\left.\mathrm{g}^{-1}\right)$ and superior to the anthocyanins content observed by Bagetti et al. (2011) in fresh purple, red and orange 'pitangas', which were respectively 136, 69 and $25 \mathrm{mg} 100 \mathrm{~g}^{-1}$. Teixeira et al (2008) found a mean of $20 \mathrm{mg}^{1} 100 \mathrm{~g}^{-1}$ of anthocyanins in strawberries, 'açaí' and 'maria pretinha' and $13 \mathrm{mg}^{1} 100 \mathrm{~g}^{-1}$ in fresh pomegranate. According to Araujo et al. (2016), the total anthocyanins content of myrtle fresh fruits can vary from 4.94 to $125.82 \mathrm{mg}^{1} 100 \mathrm{~g}^{-1}$, depending on the maturity stage.

The processing of the 'Cambui' fruit can lead to a reduction in antocyanins content, but in the present study it was observed that the originated products presented contents of this compound similar to those found in fresh fruits and generally superior to many processed food products, such as wine and grape juice, beverages considered sources of phenolics and anthocyanins. Thus, 'Cambuí' products possibly have good nutraceutical potential, since it presented high anthocyanins and high antioxidant contents, being sources of other phenolic compounds that can be beneficial to health, due to the high content of total phenolic compounds found.

\section{Conclusion}

'Cambui' presented a good potential for the elaboration of the three studied products.

The 'Cambui' products can be considered sources of antocyanins and other phenolic compounds, with high antioxidant potential.

\section{References}

AOAC International - Association of official analytical chemists, 2016. Official methods of analysis (20th Ed.). AOAC International, Rockville, MD, USA.

Apel, M.A., Lima, M.E., Sobral, M., Young, M.C., Cordeiro, I., Schapoval, E.E., Henriques, A.T, Moreno, P.R. 2010. Anti-inflammatory activity of essential oil from leaves of Myrciaria tenella and Calycorectes sellowianus. Pharmaceutical Biology, 48 (4): 433-438.

Araujo, D.R.D., Lucena, E.M.P., Gomes, J.P., Figueredo, R.M.F., Silva, C.P.D. 2016. 
Characterization of ripening stages on myrtle fruit. Revista Brasileira de Fruticultura 38(2): 1-10.

Bagetti, M., Facco, E.M.P., Piccolo, J., Hirsch, G.E., Rodriguez-Amaya, D., Kobori, C.N., Vizzotto, M., Emanuell, T. 2011. Physicochemical characterization and antioxidant capacity of pitanga fruits (Eugenia uniflora L.) Ciência e Tecnologia de Alimentos 31 (1): 147-154.

Belem, A.L.G., Branco, A.P.R. 2016. Análise florística e da distribuição espacial das espécies arbóreas do eixo de animação Arthur Bernardes, Curitiba-PR. Revista Geonorte 3(6): 583-592.

Brand-Williams, W., Cuvelier M.E.; Berset C. 1995. Use of a free radical method to evaluate antioxidant activity. Lebensmittel-Wissenschaft und-Technologie, 28: 25-30.

Cordero, R.L., Torchelsen, F.P., Overbeck, G.E., Anand, M. 2016. Invasive gorse (Ulex europaeus, Fabaceae) changes plant community structure in subtropical forest-grassland mosaics of southern Brazil. Biological Invasions. 18 (6): 1629-1643.

Harbertson, J., Spayd, S. 2006. Measuring phenolics in the winery. American Journal Enological and Viticultural 57: 280-288.

Lédo, A.S., Barin, L.B., Da Silva, A.V.C., de Sa, F.P., Machado, C. de A. 2014. In vitro germination and acclimatization of cambui tree type seedlings. Ciência Rural 44(8): 1355-1360

Lima, M.S., Silani I.M.T., Corrêa, L.C., Biasoto, A.C.T., Pereira, G.E., Bordignon-Luiz, M.T.; Ninow, J.I. 2014. Phenolic compounds, organic acids and antioxidant activity of grape juices produced from new Brazilian varieties planted in the Northeast Region of Brazil. Food Chemistry 161: 94-103.

Lorenzi, H. 2000. Árvores Brasileiras. 3. ed. São Paulo: Plantarum, v.1, 264 p.

Marques, A.T.B., Rybka, A.C.P., ARAÚJO, A.J.B. 2013. Suco, geleia e bebida alcoólica fermentada derivados de cambuí. Petrolina-PE: Empresa Brasileira de Pesquisa Agropecuária Comunicado Técnico 156.

Mota, R.V. 2006. Caracterização física e química de geleia de amora-preta. Ciência e Tecnologia de Alimentos 26: 539-543.

Ough, C.S., Amerine, M.A. 1988. Methods for analysis of musts and wines (2 ed.). New York: John Wiley and Sons, Inc.

Picinelli Lobo A., Diniero-Garcia, Y., MangasSanchez, J., Rodriguez-

Madrera, R., Suarez-Valles, B. 2009. Phenolic and antioxidant composition of cider. Journal of Food
Composition and Analysi 22: 644-648.

Pinheiro, L.R., Almeida, C.S., Silva, A.V.C. 2011. Diversidade genética de uma população natural de cambuizeiro e avaliação pós-colheita de seus frutos. Scientia Plena 7(6): 1-5.

Rizzon, L. A.; Link, M. 2006. Composição do suco de uva caseiro de diferentes cultivares. Ciência Rural, 36: 689-692.

Rizzon, L.A. Metodologia para análise de vinho. Empresa Brasileira de Pesquisa AgropecuáriaEmbrapa Uva e Vinho. Bento Gonçalves, 2010.

Rybka, A.C.P. 2010. Folatos, capacidade antioxidante e trans-2-nonenal em cerveja brasileira. 184p. (PhD Dissertation). Universidade Estadual de Campinas. Departamento de Ciência de Alimentos, Campinas.

Sessa, L., Abreo, E., Bettucci, L., Lupo, S. 2016. Botryosphaeriaceae species associated with wood diseases of stone and pome fruits trees: symptoms and virulence across different hosts in Uruguay. European Journal of Plant Pathology $1-12$.

Silva, A.V.C. da., Rabbani, A.R.C., Costa, T.S., Clivati, D. 2012. Fruit and seed biometry of cambuí (Myrciaria tenella O. Berg). Agro@mbiente Online 6 (3): 258-262.

Teixeira L.N., Stringheta P.S., Oliveira F.A. 2008. Comparação de métodos para quantificação de antocianinas. Revista Ceres 55 (4): 297-304.

Tonetti, A., Biondi, D. 2016. Dieta de capivara (Hydrochoerus hydrochaeris, L., 1766) em ambiente urbano, parque municipal do Tinguí, Curitiba-PR. Acta Veterinaria Brasilica 9(4): 316326.

Torres, A.P., Oliveira J.B., Berron L., Vaz J., Gomes O., Menezes T.R., Morais L.R.V., Silva P.F., Biasoto A.C.T., Pereira G.E. 2013. Characterization of wines from a new region of altitude in the Northeast of Brazil. Ciência e Técnica Vitivinícola 28: 260-265.

Zdunić, G. M., Menković, N. R., Jadranin, M. B., Novaković, M. M., Šavikin, K. P., \& Živković, J. Č. 2016. Phenolic compounds and carotenoids in pumpkin fruit and related traditional products. Hemijska industrija 00: 49-49. 